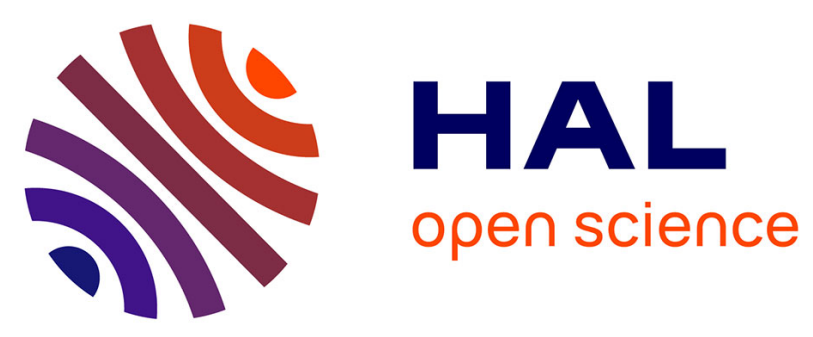

\title{
Transforming growth factor $\beta$-receptor II protein expression in benign prostatic hyperplasia is associated with prostate volume and inflammation.
}

Aurelien Descazeaud, Nicolas Weinbreck, Grégoire Robert, Francis Vacherot, Claude C. Abbou, François Labrousse, Yves Allory, Mark A. Rubin, Alexandre de La Taille

\section{To cite this version:}

Aurelien Descazeaud, Nicolas Weinbreck, Grégoire Robert, Francis Vacherot, Claude C. Abbou, et al.. Transforming growth factor $\beta$-receptor II protein expression in benign prostatic hyperplasia is associated with prostate volume and inflammation.: TGFBR2 in benign prostatic hyperplasia. BJU International, 2011, 108 (2 Pt 2), pp.E23-8. 10.1111/j.1464-410X.2010.09699.x . inserm-00609507

\section{HAL Id: inserm-00609507 https://www.hal.inserm.fr/inserm-00609507}

Submitted on 14 Sep 2011

HAL is a multi-disciplinary open access archive for the deposit and dissemination of scientific research documents, whether they are published or not. The documents may come from teaching and research institutions in France or abroad, or from public or private research centers.
L'archive ouverte pluridisciplinaire HAL, est destinée au dépôt et à la diffusion de documents scientifiques de niveau recherche, publiés ou non, émanant des établissements d'enseignement et de recherche français ou étrangers, des laboratoires publics ou privés. 


\section{Transforming growth factor $\beta$-receptor II protein expression in benign prostatic hyperplasia is associated with prostate volume and inflammation.}

Descazeaud A, Weinbreck N, Robert G, Vacherot F, Abbou CC, Labrousse F, Allory Y, Rubin MA, De La Taille A.

BJU Int. 2010 Sep 14. doi: 10.1111/j.1464-410X.2010.09699.x. [Epub ahead of print]

INSERM, Unité 841, IMRB, Créteil Urology Department, Hopital Dupuytren, CHU Limoges University Paris 12, Faculté de Médecine, Créteil Pathology Department, Hopital Dupuytren, CHU Limoges CHU de Bordeaux, Department of Urology, University of Bordeaux AP-HP, Groupe Henri-Mondor-Albert Chenevier, Department of Urology, Créteil AP-HP, Groupe Henri-Mondor-Albert Chenevier, Department of Pathology, Créteil, France Department of Pathology, Weill Cornell Medical Center, New York, NY, USA.

OBJECTIVE: • To assess transforming growth factor $\beta$-receptor II (TGFBRII) protein expression in benign prostatic hyperplasia (BPH) using immunohistochemistry analysis, and to compare the analysis with phenotypic properties.

METHODS: - TGFBRII protein expression was profiled using three clinical outcome tissue microarrays (TMAs), sampled from 231 patients who underwent Using these TMAs, five inflammatory cell markers surgery for BPH. - The were also assessed, including CD3, CD4, CD8, CD20, and CD163. - surgical procedure was open prostatectomy in 95 patients and transurethral resection of the prostate in 136 patients.

RESULTS: - TGFBRII protein expression was found in BPH epithelium cells for both basal and secretory cells, as well as in fibromuscular stromal cells. TGFBRII staining was also strong in most of the lymphocytes TGFBRII stromal staining was found to be infiltrating the prostate. - significantly associated with prostate volume $(\mathrm{P}=0.04)$, whereas TGFBRII epithelial staining was found to be significantly associated with 5 - $\alpha$ reductase-inhibitor medical therapy received by patients Both stromal and epithelial TGFBRII before surgery $(\mathrm{P}=0.004)$. $\bullet$ staining were found to be associated with CD4 Tlymphocyte infiltrate, independently of prostate volume $(\mathrm{P}<0.001$ and $\mathrm{P}=0.002)$.

CONCLUSIONS: - TGFBRII protein expression in BPH is associated with prostate gland TGFBRII might be a volume and with CD4 T-lymphocyte prostatitis. promising therapeutic target to prevent prostate enlargement or even to decrease prostate volume. 


\section{TGFBR2 protein expression in benign prostatic hyperplasia is associated with prostate volume and inflammation}

Aurelien Descazeaud (1, 2, 3), Nicolas Weinbreck (4), Grégoire Robert (5), Francis

Vacherot(1, 3), Claude C Abbou (1, 3, 6), Francois Labrousse (4), Yves Allory (1, 3, 7), Mark A Rubin (8), Alexandre de la Taille $(1,3,6)$.

First and second authors have contributed equally to this work

(1) INSERM, Unité 841, IMRB, Créteil, F-94000, France

(2) Urology department, Hopital Dupuytren, CHU Limoges, F-87000, France

(3) University Paris 12, Faculté de Médecine, Créteil, F-94000, France

(4) Pathology department, Hopital Dupuytren, CHU Limoges, F-87000, France

(5) CHU de Bordeaux, Department of Urology, University Bordeaux 2 Victor Segalen, France

(6) AP-HP, Groupe Henri-Mondor-Albert Chenevier, Department of Urology, Créteil, F94000, France

(7) AP-HP, Groupe Henri-Mondor-Albert Chenevier, Department of Pathology, Créteil, F-94000, France

(8) Department of pathology, Weill Cornell Medical Center, New York, NY, USA. 
Running Head Title: TGFBR2 in benign prostatic hyperplasia

\author{
Correspondence: \\ Dr Aurélien Descazeaud \\ Service d'urologie \\ Hopital Dupuytren \\ 2 av Martin Luther King \\ 87000 Limoges, France \\ Tel : 33555058015 \\ Fax : 33555056471 \\ Email : aureliendescazeaud@gmail.com
}

191 words summary, 2262 words manuscript, 1 figure, 3 tables, 23 references. 


\section{Summary}

Background: The aim was to assess transforming growth factor beta receptor 2 (TGFBR2) protein expression in benign prostatic hyperplasia (BPH) using an immunohistochemistry analysis, and to compare it to phenotypic properties.

Methods: TGFBR2 protein expression was profiled on three clinical outcome tissue microarrays (TMAs), including 231 patients operated for BPH. On the same TMAs, five markers of inflammatory cells were also assessed, including CD3, CD4, CD8, CD20, and CD163. Surgical procedure was open prostatectomy in 95 patients and transurethral resection of the prostate in 136 patients.

Results: TGFBR2 protein expression was found either in BPH epithelium cells for both basal and secretory cells, and in fibromuscular stromal cells. Most of lymphocytes infiltrating the prostate also showed a high TGFBR2 staining. TGFBR2 stromal staining was found significantly associated with prostate volume $(p=0.04)$ whereas TGFBR2 epithelial staining was found significantly associated with with 5 alpha reductase inhibitor medical therapy received by patients prior to surgery $(\mathrm{p}=0.004)$. Both stromal and epithelial TGFBR2 staining were found associated with CD4 T-lymphocytes infiltrate, independently of prostate volume $(\mathrm{p}<0.001$ and $\mathrm{p}=0.002)$.

Conclusion: TGFBR2 protein expression in BPH is associated with prostate gland volume and with CD4 T-lymphocyte prostatitis. TGFBR2 could be a promising therapeutic target to prevent prostate enlargement or even to decrease prostate volume.

Key Words: TGFBR2, BPH, prostate, volume, inflammation. 


\section{Introduction}

Benign prostatic hyperplasia $(\mathrm{BPH})$ is one of the most common diseases affecting aging men. Clinicians commonly use the term BPH to describe a clinical syndrome consisting of three components: lower urinary tract symptoms (LUTS), benign prostatic enlargement, and bladder outlet obstruction [1]. BPH is histologically defined as overgrowth of the epithelial and stromal cells of the transition zone and periuretral area. So far, a variety of growth factors associated with epithelial/stromal interaction have been described in the pathophysiology of $\mathrm{BPH}$ but the cellular and molecular processes underlying the pathogenesis and development of BPH remain poorly understood [2].

TGFBR2, transforming growth factor beta receptor II, is a transmembrane protein that has an intrinsic serine-threonine kinase activity and signals through a heterodimeric complex with another receptor protein (TGFBR1) that binds TGF-beta [3]. This receptor/ligand complex phosphorylates proteins, which then enter the nucleus and regulate the transcription of a subset of genes related to cell proliferation.

In a previous published study, our group found TGFBR2 to be upregulated at the RNA level in large prostate glands compared to smaller ones [4]. In another previous publication, inflammatory cells infiltrate within BPH was characterized and the role of inflammation in BPH development was highlighted by the strong correlation between histological inflammation, IPSS, and prostate volume. [5]. The goal of the current study was to assess TGFBR2 expression at the protein level in BPH using immunohistochemistry (IHC) analysis, and to compare it to phenotypic properties and inflammation. 


\section{Material and Methods}

\section{BPH Samples}

TGFBR2 was profiled on three clinical outcome tissue microarrays (TMAs), including 231 patients operated for BPH. Surgical procedure was open prostatectomy in 95 patients and transurethral resection of the prostate (TURP) in 136 patients. Characteristics of patients are presented in Table 1. TMAs contained four cores per patient. Prostate tissue was obtained after written consent from each patient and was approved by the local ethics committee.

Out of 231 patients, 217 had symptomatic BPH. Fourteen patients underwent BPH surgery with a diagnostic purpose: they had a suspicion of prostate cancer on the basis of prostate specific antigen (PSA) serum level, but they did not have LUTS requiring surgery. Prostate volume was calculated on transrectal ultrasonography. The presence of a median BPH lobe was assessed during the surgical procedure. Medical BPH treatment was considered when received by patients for at least 3 months before surgery. This treatment was 5 alpha reductase inhibitor (5ARI) alone in 9 patients, alpha blocker therapy in 53 patients, phytotherapy in 6 patients, and 5ARI / alpha blocker association in 10 patients.

On pathology, BPH was associated to inflammation in 78 patients. Inflammation was defined by the presence of more than dispersed lymphocytes, plasma cells, neutrophils or macrophages in the fibromuscular stroma and/or in the glandular ducts and acini. 
TGFBR2 IHC staining was performed on the Ventana Benchmark XT Automated Platform (Ventana Medical Systems, Tucson, AZ, USA) using the Ventana I.View DAB Detection kit, according to the manufacturer's recommended protocol. Briefly, sections of 4- $\mu \mathrm{m}$ thick paraffin-embedded TMA were dewaxed and rehydrated with xylene and ethanol. Slides were pretreated in $10 \mathrm{mM}$ citrate buffer $(\mathrm{pH} 8.0)$ for optimal antigen retrieval, before being incubated with the primary antibody against TGFBR2 (TGFBR2 anti-Human Polyclonal Antibody, Lifespan Biosciences, Seattle, WA, USA) in a 1:20 dilution for 32 minutes. Optimal primary antibody concentration was determined by serial dilutions, optimizing for the most discriminating signal without background immunostaining. The antigen-antibody complex was then detected with the I.View DAB Detection kit (Ventana). The slides were counterstained with hematoxylin. Appropriate positive controls were performed.

Five markers of inflammation were also evaluated by IHC on the same TMAs. Antibodies (Ab) decorating T-lymphocytes were CD3. CD4 and CD8 markers were used to differentiate T4-lymphocytes from T8-lymphocytes. B-lymphocytes were marked by CD20, and macrophages were marked by CD163. After antigen retrieval, the sections were processed on a Ventana nexes automated system (Ventana Medical System) using the Ventana Basic DAB detection kit according to the manufacturer's instructions. The list of antibodies used for IHC analyses is presented in table 2 .

Scoring of TGFBR2 protein expression and IHC inflammation markers 
The intensity of TGFRB2 immunostaining was graded by two independent observers $(\mathrm{AD}, \mathrm{NW})$ as absent, low, or high. For each TMA, glandular epithelium and stromal compartments were quoted separately. Both color extent and color intensity were used to grade immunostaining. "Absent" was defined as no staining at all. "Low" was defined as patchy and/or weak staining, and "high" as a strong and diffused staining (figure 1). Reproducibility of the method was tested on 100 samples that were evaluated by each observer twice. Kappa coefficient was 0.91 and 0.93 for observer one and two, respectively. Kappa coefficient between observer one and two was 0.85. IHC inflammatory cells markers were quoted as absent or present by two independent observers $(\mathrm{AD}, \mathrm{NW})$. When the two observers disagreed, then the cases were read again to finally find a consensus.

\section{Statistical Analysis}

IHC grade intensity of each patient was obtained from assessing the maximal stain intensity of all valid cores from the same patient. For example, if only one out of four cores had a "high" score, the patient would be assigned a "high"score. At least one valid core per patient was required. TGFBR2 stain intensity was first compared to clinical and pathological parameters using Fisher test and Kruskall-Wallis test for qualitative and quantitative data, respectively. TGFBR2 was considered as a qualitative ordinal data. Then, TGFBR2 staining was compared to inflammatory cells infiltrate using a Kendall's tau-b non parametric test. Additional statistics were performed to compare binary variables to qualitative and quantitative date using Chi-square test and Student $\mathrm{T}$ test, 
respectively. Commercially available software was used for statistical analyses (SPSS inc., Chicago, USA). 


\section{Results}

\section{TGFBR2 staining (figure 1)}

Stromal staining was assessed in all 231 patients with a mean valid core per patient of 3.4. Glandular epithelial staining was assessed in 202 patients, with a mean valid core per patient of 2.3. TGFBR2 expression was found either in BPH epithelium cells (for both basal and secretory cells), and in fibromuscular stromal cells. TGFBR2 stromal staining was absent, low and high in $16 \%, 66 \%$, and $18 \%$ of patients, respectively. TGFBR2 epithelial staining was absent, low and high in $7 \%, 56 \%$, and $36 \%$ of patients, respectively (table 1).

Most of lymphocytes showed a high TGFBR2 staining (figure 1d). Lymphocytes' staining was of course not taken in account to assess epithelial and stromal staining.

Association with clinical and pathological parameters (Table 1)

TGFBR2 stromal staining was found significantly associated with prostate volume whereas epithelial staining was not. TGFBR2 stromal staining was also significantly associated with the type of surgery $(\mathrm{p}=0.003)$.

TGFBR2 epithelial staining was found significantly associated with inflammation as assessed on pathology. Mean prostate volume was $71 \mathrm{ml}$ (Standard deviation 38) in cases with no inflammation, whereas it was $65 \mathrm{ml}$ (Standard deviation 35) in those with inflammation $(\mathrm{p}=0.3)$. 
TGFBR2 staining was not found associated to LUTS, presence of median lobe, and serum PSA level.

TGFBR2 protein expression was also compared to medical therapy received by patient prior to surgery. TGFBR2 epithelial staining was significantly associated with 5ARI therapy $(p=0.004)$. No significant association was found between 5ARI therapy and prostate volume $(67 \mathrm{ml}$ and $69 \mathrm{ml}$ in the groups with and without 5ARI therapy, respectively, Student $\mathrm{T}$ test $\mathrm{p}=0.8$ ). In addition, no significant association was found between 5ARI therapy received by patients and inflammation on pathology: $47 \%$ of patients had inflammation in the 5ARI therapy group versus $32 \%$ in the remaining patients group (Chi square test $\mathrm{p}=0.2$ ). Finally, in multivariable analysis, 5ARI therapy and inflammation on pathology were both associated with TGFBR2 epithelial staining (logistic regression $\mathrm{p}=0.013$ and $\mathrm{p}=0.002$, respectively).

Association with inflammatory cells infiltrate assessed on IHC (Table 3)

TGFBR2 protein expression was also compared to five markers of inflammatory cells infiltrate assessed with IHC. It was found a significant association between TGFBR2 epithelial staining and CD4 expression ( $\mathrm{p}=0.002)$, and between TGFBR2 stromal staining and CD4 $(\mathrm{p}=<0.001), \mathrm{CD} 8(\mathrm{p}=0.046)$, and CD20 expressions $(\mathrm{p}=0.003)$. Prostate volume was associated with CD3, CD4, CD8, and CD20 expressions ( $p=0.006, p<0.001$, $\mathrm{p}<0.001$, and $\mathrm{p}=0.03$, respectively, student $\mathrm{T}$-test, data not shown). In multivariate logistic regression analysis, TGFBR2 staining was associated with CD4 expression, independently of prostate volume $(\mathrm{p}<0.001$ and $\mathrm{p}=0.001$ for stromal and epithelial staining, respectively). 


\section{Discussion}

TGFBR2 protein expression was assessed in $231 \mathrm{BPH}$ patients using a large scale TMA. It was found a significant association between TGFBR2 stromal staining and prostate volume. It was also found an association between TGFBR2 staining and inflammation in BPH (assessed on standard pathology and using IHC). In particular, cases with CD4 Tlymphocytes infiltrate within the prostate gland were more likely to have stromal and glandular TGFBR2 expression. Finally, we highlighted a significant association between epithelial staining and 5ARI therapy.

Our group previously published a list of genes supposed to be associated with prostate volume [4]. TGFBR2 was one of these. As described by other authors, gene array analyses have major limitations [6], and, therefore, should be validated by analyses using other methods. In the present study, we confirm at the protein level what we found at the RNA level.

Patients with large prostate glands were more likely to be operated by prostatectomy, whereas those with smaller prostate glands were preferentially operated through a transurethral approach. This might explain the fact that both the operative technique and the prostate volume were associated with TGFBR2 stromal staining.

It was previously shown that TGFB proteins and their receptors might have a role in BPH pathogenesis [7-9]. First, they might be under an androgen influence. They were found downregulated by androgen and upregulated by castration in murine prostate $[\mathbf{1 0 , 1 1}]$. Dhanasekaran et al [12] compared gene expression between adult and pubertal prostates. Change of the prostate gland at puberty is a crucial juncture in prostate development that 
is androgen dependent. These authors found TGFBR2 and TGFBR3 to be upregulated at the RNA level in the pubertal prostates compared to adult ones. They also observed a greater stromal to epithelial ratio in the pubertal prostates.

TGFB has been shown to be a regulator of stromal proliferation and differentiation in BPH [13]. Androgen may control the proliferation and differentiation of prostatic stromal cells by regulating the expression of TGFB [14]. Luo et al. [15] compared RNA expression using c-DNA microarrays in $9 \mathrm{BPH}$ samples and 12 normal prostate tissues excised from radical prostatectomy specimen. They supposed that TGFB1 and TGFBR2 were downregulated and TGFB3 and TGFBR3 upregulated in BPH compared to normal prostate tissue. They confirmed that TGFB3 was upregulated in BPH using a semiquantitative RT-PCR method. They did not confirm their finding on TGFBR2 at the protein level. At the opposite, for Pavelic et al. [16], TGFB1 and TGFB2 were upregulated and TGFB3 is downregulated in BPH compared to normal transition zone.

TGFB1 is classically considered to be inhibitory for epithelial cells [17]. In vitro, Untergasser et al [18] showed that TGFB1 treated cells compared to senescent cells, morphologically transdifferentiated into myofibroblasts with dense cytoskeletal fibers and increased expression of smooth muscle cells. Prakash et al. [19] compared RNA expression using c-DNA Microarrays in 5 samples from patients with asymptomatic BPH to 8 samples from patients with symptomatic BPH. They found a set of 511 differentially expressed genes distinguishing symptomatic and asymptomatic BPH. In particular, TGFB2 was upregulated in symptomatic BPH compared to asymptomatic BPH. Similarly, we compared TGFBR2 protein expression in symptomatic and asymptomatic 
BPH cases. We did not observe any significant difference between these two groups. This might be due to the low number of asymptomatic BPH cases $(\mathrm{N}=14)$ in our series.

TGFBR2 was found significantly associated to 5ARI therapy. We were concerned by a possible confusing factor due to a possible association between 5ARI therapy and prostate volume, but patients treated by 5ARI had, on average, lower prostate volume than others. In addition, in multivariable analysis, 5ARI therapy and inflammation on pathology were both associated with TGFBR2 epithelial staining. Therefore we made the hypothesis that 5ARI could increase TGFBR2 protein expression in BPH tissue. As 5ARI therapy was previously proven to have an effect on prostate volume and on postoperative bleeding in patients operated for BPH [1, 20, 21], we were not surprised to observe that 5ARI could modify the level of a growth factor such as TGFBR2 within BPH tissue.

To our knowledge, here is the first report assessing an association between TGFBR2 protein expression and inflammation. TGFBR2 epithelial staining was associated with inflammation on pathology. In addition, both stromal and epithelial staining was found associated with epithelial CD4 lymphocyte infiltrate, independently of prostate volume. It means that cases with CD4 lymphocytes infiltrate were more likely to express TGFBR2 protein within $\mathrm{BPH}$ tissue. The relationship between $\mathrm{BPH}$ and inflammation was previously described $[5, \mathbf{2 2}, \mathbf{2 3}]$. One hypothesis is that inflammation could stimulate the production of growth factors such as TGFBR2, which could lead to BPH development and prostate overgrowth. Further studies should explore the exact role of the relationship between inflammation and TGFBR2 in the pathogenesis of BPH. 
Overall, TGFB proteins and receptors, and TGFBR2 in particular, may play an important role in BPH pathogenesis: being under an androgen influence, they might stimulate tissue proliferation and differentiation, and modify stromal/epithelial ratio.

Prostate volume is known to have a real impact on BPH: baseline prostate size can be considered a strong indicator of BPH progression, particularly for acute urinary retention and BPH-related surgery but also for long-term changes in symptoms, bother, quality of life, and flow rate [20]. As TGFBR2 is associated with prostate volume, it might be a therapeutic target in $\mathrm{BPH}$ to prevent prostate enlargement or even to decrease prostate volume. 


\section{References}

1. Nickel JC. Benign prostatic hyperplasia: does prostate size matter? Rev Urol 2003:5:S12-7.

2. Lee KL, Peehl DM. Molecular and cellular pathogenesis of benign prostatic hyperplasia. J Urol 2004: 172:1784-91.

3. Paik SY, Park YN, Kim H, Park C. Expression of transforming growth factorbeta1 and transforming growth factor-beta receptors in hepatocellular carcinoma and dysplastic nodules. Mod Pathol 2003:16:86-96.

4. Descazeaud A, Rubin MA, Hofer M, et al. BPH gene expression profile associated to prostate gland volume. Diagn Mol Pathol 2008:17:207-13.

5. Robert G, Descazeaud A, Nicolarew N, et al. Inflammation in Benign Prostatic Hyperplasia: A 282 Patients' Immunohistochemical Analysis. The Prostate 2009: 69:1774-80.

6. Stamey TA, Caldwell MC, Fan Z, et al. Genetic profiling of Gleason grade $4 / 5$ prostate cancer: which is the best prostatic control tissue? J Urol 2003:170:226368.

7. Mori H, Maki M, Oishi K, et al. Increased expression of genes for basic fibroblast growth factor and transforming growth factor type beta 2 in human benign prostatic hyperplasia. Prostate 1990: 16:71-80.

8. Steiner MS. Review of peptide growth factors in benign prostatic hyperplasia and urological malignancy. J Urol 1995:153:1085-96.

9. Royuela M, De Miguel MP, Bethencourt FR, Sanchez-Chapado M, Fraile B, Paniagua R. Transforming growth factor beta 1 and its receptor types I and II. Comparison in human normal prostate, benign prostatic hyperplasia, and prostatic carcinoma. Growth Factors 1998: 16:101-10.

10. Kyprianou N, Isaacs JT. Expression of transforming growth factor beta in the rat ventral prostate during castration-induced programmed cell death. Mol Endocrinol 1989: 3:1515-22. 
11. Kim IY, Ahn HJ, Zelner DJ, Park L, Sensibar JA, Lee C. Expression and localization of transforming growth factor-beta receptors type I and type II in the rat ventral prostate during regression. Mol Endocrinol 1996:10:107-15.

12. Dhanasekaran SM, Dash A, Yu J, et al. Molecular profiling of human prostate tissues: insights into gene expression patterns of prostate development during puberty. FASEB J 2005:19:243-45.

13. Huang $\mathrm{X}$, Lee C. Regulation of stromal proliferation, growth arrest, differentiation and apoptosis in benign prostatic hyperplasia by TGF-beta. Front Biosci 2003:8:s740-49.

14. Niu Y, Xu Y, Zhang J, Bai J, Yang H, Ma T. Proliferation and differentiation of prostatic stromal cells. BJU Int 2001:87:386-93.

15. Luo J, Dunn T, Ewing C, Sauvageot J, Chen Y, Trent J, Isaacs W. Gene expression signature of benign prostatic hyperplasia revealed by cDNA microarray analysis. Prostate 2002:51:189-200.

16. Pavelić J, Zeljko Z, Bosnar MH. Molecular genetic aspects of prostate transition zone lesions. Urology 2003:62:607-13.

17. Byrne RL, Leung H, Neal DE. Peptide growth factors in the prostate as mediators of stromal epithelial interaction. Br J Urol 1996: 77:627-33.

18. Untergasser G, Gander R, Lilg C, Lepperdinger G, Plas E, Berger P. Profiling molecular targets of TGF-betal in prostate fibroblast-to-myofibroblast transdifferentiation. Mech Ageing Dev 2005:126:59-9.

19. Prakash K, Pirozzi G, Elashoff M, et al. Symptomatic and asymptomatic benign prostatic hyperplasia: molecular differentiation by using Microarrays. Proc Natl Acad Sci U S A 2002:99:7598-7603.

20. Ozdal OL, Ozden C, Benli K, Gökkaya S, Bulut S, Memiş A. Effect of short-term finasteride therapy on peroperative bleeding in patients who were candidates for transurethral resection of the prostate (TUR-P): a randomized controlled study. Prostate Cancer Prostatic Dis. 2005:8(3):215-8.

21. Speakman M, Batista $J$, Berges $R$, et al. Integrating risk profiles for disease progression in the treatment choice for patients with lower urinary tract 
symptoms/benign prostatic hyperplasia: a combined analysis of external evidence and clinical expertise. Prostate Cancer Prostatic Dis. 2005:8(4):369-74.

22. Nickel JC. Inflammation and benign prostatic hyperplasia. Urol Clin North Am 2008:35:109-15.

23. Kramer G, Mitteregger D, Marberger M. Is benign prostatic hyperplasia (BPH) an immune inflammatory disease? Eur Urol 2007:51:1202-16. 
Legend of figure 1:

TGFBR2 IHC staining in BPH (x 400). A: Glandular epithelial compartment with high staining. B: Stromal compartment with high staining. C: High staining in epithelial cells and in inflammatory cells. D: Absence of staining in glandular and stromal compartments

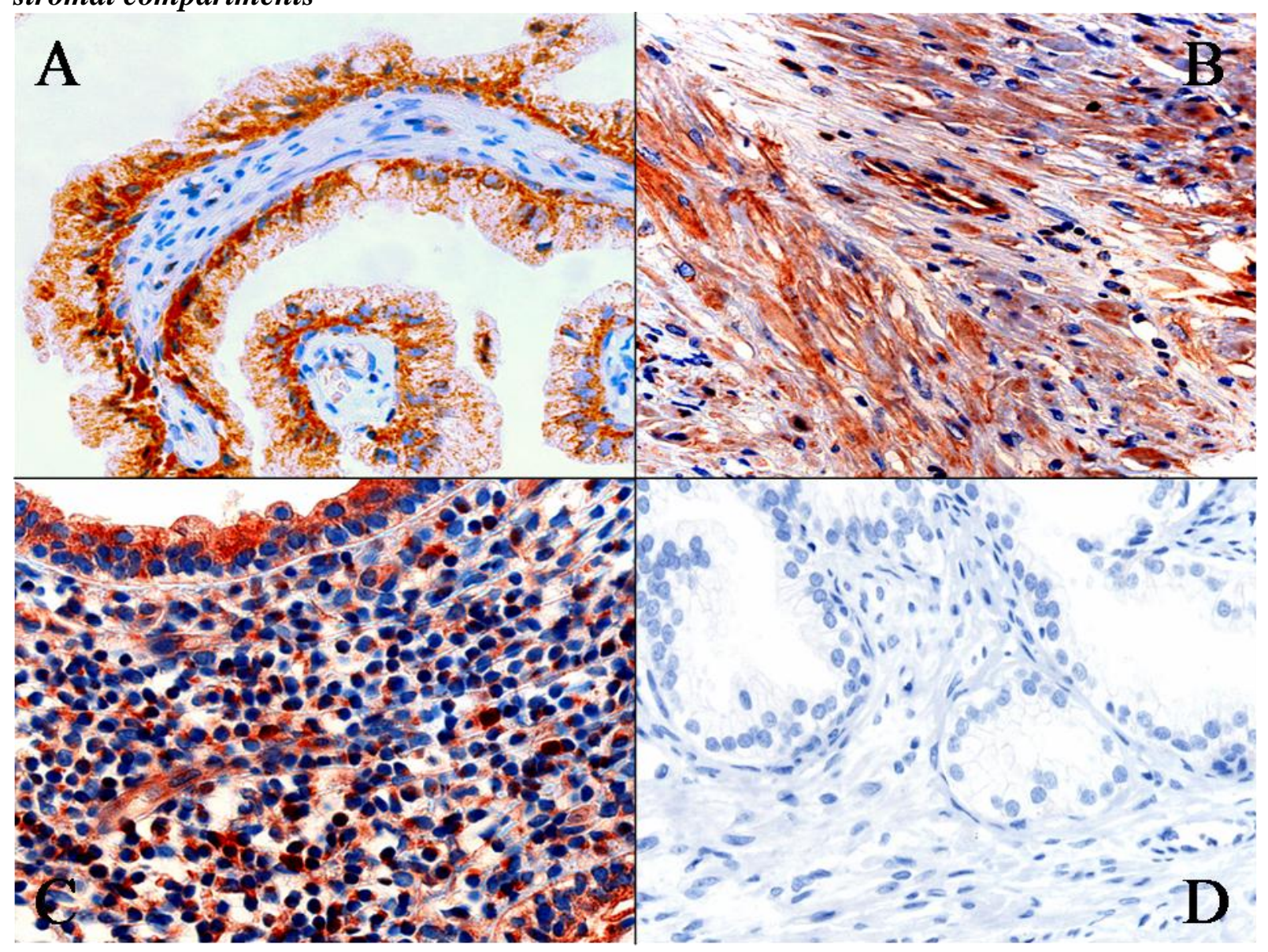

No conflict of interest 
Table 1: Association between TGFBR2 protein expression and clinical and pathological parameters (*Fisher test, ${ }^{* *}$ Kruskall-Wallis test)

\begin{tabular}{|c|c|c|c|c|c|c|c|c|c|c|}
\hline & & Total & \multicolumn{4}{|c|}{ Sromal staining $(\mathrm{N}=\mathbf{2 3 1})$} & \multicolumn{4}{|c|}{ Epithelial staining $(\mathrm{N}=202)$} \\
\hline & & & absent & low & high & $\mathrm{p}$ & absent & low & high & $\mathrm{p}$ \\
\hline $\mathrm{N}$ & & 231 & $\begin{array}{c}37 \\
(16 \%)\end{array}$ & $\begin{array}{c}153 \\
(66 \%)\end{array}$ & $\begin{array}{c}41 \\
(18 \%)\end{array}$ & & $\begin{array}{c}15 \\
(7 \%)\end{array}$ & $\begin{array}{c}114 \\
(56 \%)\end{array}$ & $\begin{array}{c}73 \\
(36 \%)\end{array}$ & \\
\hline Mean age & Range 50-91 & $\mathrm{N}=70$ & 71.8 & 69.3 & 70.8 & $0.6^{* *}$ & 70.2 & 70.8 & 68.8 & $0.6^{* *}$ \\
\hline Histology & $\begin{array}{l}\text { BPH with no } \\
\text { inflammation }\end{array}$ & $\begin{array}{l}\mathrm{N}= \\
153\end{array}$ & $\begin{array}{c}27 \\
(17 \%)\end{array}$ & $\begin{array}{c}101 \\
(67 \%)\end{array}$ & $\begin{array}{c}25 \\
(15 \%)\end{array}$ & \multirow{2}{*}{$0.3^{*}$} & $\begin{array}{c}13 \\
(10 \%)\end{array}$ & $\begin{array}{c}88 \\
(63 \%)\end{array}$ & $\begin{array}{c}39 \\
(27 \%)\end{array}$ & \multirow{2}{*}{ 0.001* } \\
\hline & $\begin{array}{l}\text { BPH with } \\
\text { inflammation }\end{array}$ & $\mathrm{N}=78$ & $\begin{array}{c}10 \\
(13 \%)\end{array}$ & $\begin{array}{c}52 \\
(67 \%)\end{array}$ & $\begin{array}{c}16 \\
(21 \%)\end{array}$ & & $2(3 \%)$ & $\begin{array}{c}26 \\
(42 \%)\end{array}$ & $\begin{array}{c}34 \\
(55 \%)\end{array}$ & \\
\hline \multirow[t]{2}{*}{ LUTS } & No & $\mathrm{N}=14$ & $1(7 \%)$ & $\begin{array}{c}11 \\
(79 \%)\end{array}$ & $2(14 \%)$ & $0.7 *$ & $0(0 \%)$ & $8(57 \%)$ & $\begin{array}{c}6 \\
(43 \%)\end{array}$ & $0.4^{*}$ \\
\hline & Yes & $\begin{array}{l}\mathrm{N}= \\
217\end{array}$ & $\begin{array}{c}36 \\
(17 \%)\end{array}$ & $\begin{array}{c}142 \\
(65 \%)\end{array}$ & $\begin{array}{c}39 \\
(18 \%)\end{array}$ & & $\begin{array}{c}15 \\
(8 \%)\end{array}$ & $\begin{array}{c}106 \\
(56 \%)\end{array}$ & $\begin{array}{c}67 \\
(36 \%)\end{array}$ & \\
\hline \multirow[t]{2}{*}{ Median lobe } & Present & $\mathrm{N}=37$ & $6(16 \%)$ & $\begin{array}{c}24 \\
(65 \%)\end{array}$ & $7(19 \%)$ & $0.9^{*}$ & $1(4 \%)$ & $\begin{array}{c}14 \\
(50 \%)\end{array}$ & $\begin{array}{c}13 \\
(46 \%)\end{array}$ & $0.2^{*}$ \\
\hline & Absent & $\begin{array}{c}\mathrm{N}=19 \\
4\end{array}$ & $\begin{array}{c}28 \\
(15 \%)\end{array}$ & $\begin{array}{c}123 \\
(67 \%)\end{array}$ & $\begin{array}{c}33 \\
(18 \%)\end{array}$ & & $\begin{array}{c}12 \\
(7 \%)\end{array}$ & $\begin{array}{c}93 \\
(57 \%)\end{array}$ & $\begin{array}{c}59 \\
(36 \%\end{array}$ & \\
\hline \multirow[t]{2}{*}{ Type of surgery } & TURP & $\begin{array}{l}\mathrm{N}= \\
136\end{array}$ & $\begin{array}{c}28 \\
(21 \%)\end{array}$ & $\begin{array}{c}90 \\
(66 \%)\end{array}$ & $\begin{array}{c}18 \\
(13 \%)\end{array}$ & 0.003* & $\begin{array}{c}11 \\
(10 \%)\end{array}$ & $\begin{array}{c}63 \\
(56 \%)\end{array}$ & $\begin{array}{c}38 \\
(34 \%)\end{array}$ & $0.3 *$ \\
\hline & Prostatectomy & $\mathrm{N}=95$ & $9(9 \%)$ & $\begin{array}{c}63 \\
(66 \%)\end{array}$ & $\begin{array}{c}23 \\
(24 \%)\end{array}$ & & $4(4 \%)$ & $\begin{array}{c}51 \\
(57 \%)\end{array}$ & $\begin{array}{c}35 \\
(39 \%)\end{array}$ & \\
\hline \multirow[t]{4}{*}{$\begin{array}{l}\text { Medical } \\
\text { Therapy }\end{array}$} & None & $\begin{array}{l}\mathrm{N}= \\
153\end{array}$ & $\begin{array}{c}28 \\
(18 \%)\end{array}$ & $94(61 \%$ & $\begin{array}{c}31 \\
(20 \%)\end{array}$ & & $\begin{array}{c}10 \\
(7 \%)\end{array}$ & $\begin{array}{c}82 \\
(61 \%)\end{array}$ & $\begin{array}{c}43 \\
(32 \%)\end{array}$ & \\
\hline & Phytotherapy & $\mathrm{N}=6$ & $0(0 \%)$ & $\begin{array}{c}6 \\
(100 \%)\end{array}$ & $0(0 \%)$ & NA & $0(0 \%)$ & $3(75 \%)$ & $\begin{array}{c}1 \\
(25 \%)\end{array}$ & NA \\
\hline & Alpha - & $\mathrm{N}=63$ & $8(13 \%)$ & $\begin{array}{c}49 \\
(78 \%)\end{array}$ & $6(10 \%)$ & $0.8^{*}$ & $5(9 \%)$ & $\begin{array}{c}29 \\
(53 \%)\end{array}$ & $\begin{array}{c}21 \\
(38 \%)\end{array}$ & $0.8^{*}$ \\
\hline & 5ARI & $\mathrm{N}=19$ & $3(16 \%)$ & $\begin{array}{c}12 \\
(63 \%)\end{array}$ & $4(21 \%)$ & $0.4^{*}$ & $0(0 \%)$ & $4(27 \%)$ & $\begin{array}{c}11 \\
(73 \%)\end{array}$ & 0.004* \\
\hline $\begin{array}{l}\text { Mean PSA } \\
(\mathrm{ng} / \mathrm{ml})\end{array}$ & $\begin{array}{l}\text { Median 5.4 } \\
\text { Range 0.5-43 }\end{array}$ & 10.4 & 7.9 & 10.5 & 12.0 & $0.3 * *$ & 4.6 & 12.2 & 10.0 & $0.9 * *$ \\
\hline $\begin{array}{l}\text { Mean Prostate } \\
\text { volume }(\mathrm{ml})\end{array}$ & $\begin{array}{l}\text { Median } 60 \\
\text { Range 20-220 }\end{array}$ & 69 & 59,8 & 69.2 & 76.9 & $0.04 * *$ & 63.3 & 72.1 & 71.5 & $0.7^{* *}$ \\
\hline
\end{tabular}


Table 2: List of antibodies used for IHC analyses

\begin{tabular}{|l|l|l|l|}
\hline Target & Antibody & Manufacturer & Dilution \\
\hline TGFBR2 & $\begin{array}{l}\text { anti-Human } \\
\text { Polyclonal Antibody }\end{array}$ & $\begin{array}{l}\text { Lifespan } \\
\text { Biosciences }\end{array}$ & $1: 20$ \\
\hline CD3 & $\begin{array}{l}\text { rabbit polyclonal Ab } \\
\text { A0452 }\end{array}$ & Dako & $1: 300$ \\
\hline CD4 & $\begin{array}{l}\text { mouse monoclonal } \\
\text { Ab clone 4B12 }\end{array}$ & $\begin{array}{l}\text { Novocastra- } \\
\text { Menarini }\end{array}$ & $1: 20$ \\
\hline CD8 & $\begin{array}{l}\text { mouse monoclonal } \\
\text { Ab clone C8/144B }\end{array}$ & Dako & $1: 200$ \\
\hline CD20 & $\begin{array}{l}\text { mouse monoclonal } \\
\text { Ab clone L26 }\end{array}$ & Dako & $1: 500$ \\
\hline CD163 & $\begin{array}{l}\text { mouse monoclonal } \\
\text { Ab clone 10D6 }\end{array}$ & $\begin{array}{l}\text { Novocastra- } \\
\text { Menarini }\end{array}$ & $1: 800$ \\
\hline
\end{tabular}


Table 3: Cross tabulation of TGFBR2 expression and IHC markers of inflammation infiltrate (Kendall's tau-b non parametric test)

\begin{tabular}{|l|l|c|c|c|c|c|c|c|c|}
\hline \multirow{2}{*}{$\begin{array}{l}\text { IHC } \\
\text { marker }\end{array}$} & & \multicolumn{3}{|l}{ Sromal staining (N=268) } & \multicolumn{3}{l|}{ Epithelial staining (N=238) } \\
\hline CD3 & Absent & low & high & $\mathrm{p}$ & absent & low & high & P \\
\cline { 2 - 10 } & Present & 23 & 124 & 32 & & 12 & 89 & 63 & \\
\hline CD4 & Absent & 32 & 98 & 19 & $<0.001$ & 14 & 75 & 37 & 0.002 \\
\cline { 2 - 11 } & Present & 6 & 55 & 22 & & 2 & 39 & 36 & \\
\hline CD8 & Absent & 13 & 26 & 6 & 0.046 & 3 & 19 & 10 & 0.5 \\
\cline { 2 - 11 } & Present & 25 & 127 & 35 & & 13 & 95 & 63 & \\
\hline CD20 & Absent & 25 & 68 & 17 & 0.03 & 10 & 52 & 29 & 0.15 \\
\cline { 2 - 10 } & Present & 13 & 85 & 24 & & 6 & 62 & 44 & \\
\hline CD163 & Absent & 11 & 29 & 6 & 0.12 & 2 & 19 & 16 & 0.7 \\
\cline { 2 - 10 } & Present & 27 & 124 & 35 & & 14 & 95 & 57 & \\
\hline
\end{tabular}

